\title{
Infectious diseases of the skin in contact sports
}

\author{
Danuta Nowicka ${ }^{1, B-D, F}$, Marta Bagłaj-Oleszczuk ${ }^{1, B, D, F}$, Joanna Maj $j^{2, A, E, F}$ \\ ${ }^{1}$ Department of Dermatology, Venereology and Allergology, Wroclaw Medical University, Poland \\ ${ }^{2}$ Institute of Health Sciences, University of Opole, Poland \\ A - research concept and design; $B$ - collection and/or assembly of data; $C$ - data analysis and interpretation; \\ $D$ - writing the article; $E$ - critical revision of the article; $F$ - final approval of the article
}

\section{Address for correspondence \\ Danuta Nowicka}

E-mail: danuta.nowicka@umed.wroc.pl

\section{Funding sources}

None declared

\section{Conflict of interest}

None declared

Received on 0ctober 17, 2020

Reviewed on October 19, 2020

Accepted on 0ctober 28, 2020

\begin{abstract}
Although the benefits of practicing sports are unquestionable, it can contribute to the spread of skin diseases. Mechanical trauma, exposure to environmental and infectious agents, and contact with the skin of other athletes increase the chances of getting an infection. In contact sports, skin infections are responsible for up to 20\% of lost training and competition time. In the USA, skin infections, with an incidence of $8.5-20.9 \%$, are the $2^{\text {nd }}$ cause (following upper respiratory infections) of all medical consultations among young wrestlers. The high morbidity of skin diseases poses a great challenge for the diagnosis and treatment of skin infections in athletes practicing contact sports, for whom recommendations may differ from those in the general population. In this review paper, we summarize and discuss the management of infectious diseases of the skin in contact sports. The review shows that the most frequent among athletes are bacterial infections, including folliculitis, erysipelas, furuncles and inflammation of the subcutaneous tissue; viral infections caused by herpes simplex virus, human papilloma virus and molluscum contagiosum virus; fungal infections such as tinea; and infestations, including pediculosis and scabies. Preventing the spread of the infection is the $2^{\text {nd }}$ most important aspect of treatment, following pharmacotherapy. This includes avoiding contact with other athletes, protection or removal of lesions, disinfection of common sports equipment, not sharing towels or other personal equipment. We conclude that protecting against infection and transmission of pathogens in sports teams is crucial in avoiding unnecessary morbidity and minimizing dissuption to the training and competition schedule.
\end{abstract}

Key words: contact sport, skin infection, wrestling, sports

Cite as

Nowicka D, Bagłaj-Oleszzzuk M, Maj J. Infectious diseases of the skin in contact sports. Adv Clin Exp Med. 2020;29(12):1491-1495. doi:10.17219/acem/129022

DOI

10.17219/acem/129022

\section{Copyright}

Copyright by Author(s)

This is an article distributed under the terms of the

Creative Commons Attribution 3.0 Unported (CC BY 3.0)

(https://creativecommons.org/licenses/by/3.0/) 


\section{Background}

Physical activity and sports have become part of current life, even among amateur athletes. Although the benefits of sports are unquestionable, ${ }^{1}$ participating in sports can be associated with several skin problems. Mechanical trauma, exposure to environmental and infectious agents, as well as contact with various other factors and with the skin of other athletes increase the chances of getting an infection. Furthermore, physical effort often exacerbates existing dermatological lesions. ${ }^{2}$ Contact sports seem to be the disciplines with the most frequent occurrence of skin problems, the majority of which are skin infections. ${ }^{3}$ According to data from the literature, up to $20 \%$ of wrestlers lose training or competition time each year due to skin infections. Of those infections, over $22 \%$ have a recurrent nature. ${ }^{4}$ An epidemiology study conducted in the USA showed that skin infections are the $2^{\text {nd }}$ most frequent cause (following upper respiratory infections) of medical consultations among high school and college wrestlers, with an incidence of 8.5-20.9\%. ${ }^{5}$ The recommended treatment of skin infections in athletes practicing contact sports may differ from the management of skin infections in the general population. The recommendations are summarized in Table 1 and discussed further in the present review.

Diagnosing specific sports dermatoses can be challenging. In this review, we discuss and highlight some of the typical skin problems associated with practicing sports.

\section{Bacterial infections}

Infections with Staphylococcus and Streptococcus species are the most frequently seen skin and soft tissue infections in humans. In clinical practice, impetigo contagious, erysipelas, panniculitis, and furuncles are the most frequent; however, a superficial bacterial infection of the skin that causes vesicle-purulent lesions including blisters and open lesions that leave honey-yellow scabs dominates over other skin infections. Due to the superficial nature of such conditions, systemic treatment is rarely necessary. ${ }^{3}$

Folliculitis is manifested by small pustules around hair follicles. In people using tight-fitting workout clothes, folliculitis may take the form of so-called "bikini bottom". In such cases, the lesions are localized in the areas where the clothes fit. It can be treated with topical and oral antibiotics. This disease usually causes no problems in diagnosis and treatment. Although folliculitis is considered highly contagious, it is rarely the cause of lost training time. ${ }^{4}$ Nevertheless, it is advisable to reduce the intensity of training and to avoid contact with other athletes for at least $72 \mathrm{~h}$ from the start of the treatment. Body shaving may contribute to increased frequency of folliculitis. ${ }^{6}$

Deep bacterial infections such as erysipelas, furuncles or inflammations of the subcutaneous tissue have been reported to occur equally often in contact and in group sports such as football and basketball., ${ }^{7,8}$ Direct contact seems to be crucial for contracting these contagious diseases; however, some of the authors highlight the role of mats and equipment in spreading infections. ${ }^{9}$ What

Table 1. Skin infections: Recommendations and treatment for athletes practicing contact sports

\begin{tabular}{|c|c|c|}
\hline Disease & Recommendations & Treatment \\
\hline Bacterial infections & $\begin{array}{l}\text { Avoid contact with other athletes for at least } 72 \mathrm{~h} \text { from } \\
\text { the start of the treatment or if new lesions appeared during } \\
48 \mathrm{~h} \text { or if moist exudative lesions are present. } \\
\text { Avoid body shaving. }\end{array}$ & Antibiotics \\
\hline HSV viral infection & $\begin{array}{l}\text { Before a competition, all lesions must be dry and covered with } \\
\text { crusts. } \\
\text { Avoid contact with other athletes if new lesions appeared for } \\
\text { during last } 72 \mathrm{~h} \text { or systemic symptoms are present or for at least } \\
120 \mathrm{~h} \text { from the start of antivirals. }\end{array}$ & $\begin{array}{l}\text { Topical antivirals for skin lesions; systemic antivirals for } \\
\text { massive skin lesions and systemic symptoms. }\end{array}$ \\
\hline MCV viral infection & $\begin{array}{l}\text { Participation is allowed immediately after removal of lesions. } \\
\text { Treated sites must be covered with a bio-occlusive dressing. }\end{array}$ & Removal of lesions (curetting, cryotherapy). \\
\hline Fungal infections: Tinea & $\begin{array}{l}\text { Participation is allowed after } 72 \mathrm{~h} \text { from the start of treatment } \\
\text { in case of skin tinea and } 14 \text { days in case of tinea capitis. }\end{array}$ & $\begin{array}{l}\text { Topical antifungal cream twice daily; cover a lesion } \\
\text { and } 2 \mathrm{~cm} \text { surrounding skin. } \\
\text { For tinea capitis, systemic antifungal treatment plus } \\
2 \% \text { ketoconazole shampoo. } \\
\text { Followed by maintenance treatment. } \\
\text { Relapse prevention - shampoo 1-2 times a week. }\end{array}$ \\
\hline Infestations: Pediculosis & $\begin{array}{l}\text { Participation is allowed after } 24 \mathrm{~h} \text { from the start of treatment } \\
\text { unless active infestation is present. }\end{array}$ & $\begin{array}{l}\text { 1\% permethrin shampoo once and repeated } \\
3-7 \text { days after if pediculosis persists. }\end{array}$ \\
\hline Infestations: Scabies & $\begin{array}{l}\text { Participation is allowed after } 24 \mathrm{~h} \text { from the start of treatment if no } \\
\text { evidence of active infestation in skin scrapings. }\end{array}$ & One application of 5\% permethrin topical cream. \\
\hline
\end{tabular}

HSV - herpes simplex virus; MCV - molluscum contagiosum virus. 
seems to be necessary for stopping the spread of an infection is quick diagnosis, treatment and isolation of the sick athlete. If the infection spreads, it also seems necessary to identify the carriers, e.g., by collecting and testing bacteriological swabs from body cavities. The treatment of deep bacterial infections may be challenging, due to much higher skin colonization rates with methicillin-resistant Staphylococcus aureus among athletes. In wrestlers, carriage may reach $76 \%$ in comparison to $18 \%$ in people who do not practice any sport. ${ }^{10}$

\section{Viral infections of the skin and mucosa}

Common viral infections that afflict athletes include those caused by herpes simplex virus (HSV), human papilloma virus (HPV) and molluscum contagiosum virus (MCV). Herpes simplex can occur in any location, especially in contact sports. The HSV infection can be easily contracted, resulting in massive outbreaks during athletic training camps..$^{11-13}$ In this context it is called herpes gladiatorum, a term which was used as early as the 1960s, but which came into widespread use in $1989,{ }^{14}$ when 60 of 175 participants of a Minnesota (USA) high-school wrestling camp presented with signs of HSV infection, forcing the US Department of Public Health to disband the camp. ${ }^{11}$ The clinical picture of HSV infection often includes massive, painful follicular lesions in groups or a rash of blisters at the site of infection. In the literature, facial presentation is the most common (up to 70\%). Lesions located on the fingers or thumbs, on the extremities and the trunk constitute the remaining $30 \%$ of cases. ${ }^{11,15}$

Coexisting dermatoses, mainly atopic dermatitis or contact eczema, may increase the risk of HSV skin infection. Involvement of the eye is also possible. Herpetic keratitis (involvement of the cornea) can lead to scarring, and with repeated lesions, it can lead to permanent corneal opacity, requiring a corneal transplant to maintain good vision. Retinal necrosis leading to blindness may also occur. Retinal necrosis due to HSV infection is the most common cause of blindness of contagious origin in the USA. ${ }^{16-18}$ The treatment of HSV infection is based on antivirals (e.g., acyclovir, ganciclovir) given in cases of high intensity of general symptoms. In cases of eye involvement, an ophthalmologic consultation is required. Antibiotic therapy may become necessary after secondary bacterial infection.

The MCV is highly infectious and spreads through contact with the content of skin lesions. As in the case of herpes, atopic diseases increase the risk of contracting the infection. In most cases, active treatment is not necessary. Extensive and complicated lesions, as well as those causing esthetic problems, may be subjected to mechanical, chemical or pharmacological treatment. ${ }^{19}$ In sports, it should be treated as early as possible using mechanical methods to reduce the chances of the infection spreading among the athletes. ${ }^{20}$ Warts are lesions caused by MCV types 1 , 2 and 3, as well as 6, 11, 16 and 18. Lesions such as papules can appear all over the skin, with a predilection for the dorsal surface of the hand, the soles of the feet and the face. The source of infection can be direct contact with other infected persons, but also through uneven, moist surfaces (shower floors, sauna benches, exercise mats). Studies show that MCV spreads easily among swimmers through shared use of towels and wet surfaces, and is a cause of frequent outbreaks of molluscum contagiosum in athletes practicing water sports. ${ }^{7,21}$ The management of MCV infections should be focused primarily on prophylaxis (wearing protective shoes) as well as on the destruction of the lesions (e.g., with laser surgery or cryotherapy), or application of imiquimod, salicylic acid or podophyllin. ${ }^{19}$ Propagation of good hygienic practice is recommended as well, e.g., avoiding sharing towel and personal equipment, and using only disinfected mats. ${ }^{7,21,22}$

\section{Fungal infections}

Athletes are at high risk of fungal infections caused by dermatophytes due to increased exposure to pathogens (e.g., swimmers through contact with water, wrestlers through using mats) and repeated exposure to mechanical factors (e.g., microinjuries of the skin of runners' feet). In disciplines involving close contact during competitions, particularly in wrestlers and judokas, anthropophilic infections with Trichophyton tonsurans (tinea gladiatorum) play the greatest role. Some studies report that infections with T. tonsurans were detected in at least 1 athlete in up to $84 \%$ of the wrestling teams in the USA. ${ }^{23}$ Tinea gladiatorum is highly contagious and often causes minor epidemics, especially if the primary source of infection is not quickly identified. The sports environment (e.g., mats) and asymptomatic carriers may be involved in the further spread of this disease. In sumo wrestlers, for example, the scalp often serves as the reservoir of the pathogen. ${ }^{3}$ It seems that tinea pedis is often underdiagnosed and undertreated. Colonization of the environment by fungal spores may be responsible for the much higher level of fungal infections of the feet in children and adolescents who practice sports. Infections of the toenails (onychomycosis) are more frequent than fingernail infections. They may result in the separation of the nail from the nail bed and pave the way for secondary bacterial or mold infections. On the other hand, zoophilic and geophilic dermatophytes are rarely transmitted to athletes who have contact with animals, e.g., equestrians. ${ }^{24}$

Dermatophytes infect the stratum corneum (tinea corporis), but also the hair and hair follicles in the scalp area (tinea capitis). In children and adolescents involved in contact sports, the infection leads to endothrix on the scalp, with parasitic spores visible within the hair shaft and undamaged hair cuticle, often called black-dot ringworm. 
In contrast, in adults, it leads to asymptomatic carriage. ${ }^{25}$ Transmitting pathogens and contracting the disease depend not only on contract with an infected person, but also on other factors, such as the occurrence of sports-related abrasions, an unfavorable indoor climate, the intensity of sweating, and the time between competition and shower. Majocchi granuloma may also develop in cases of local or systemic immunosuppression. ${ }^{26}$

In contact sports, tinea corporis presents with pruritic and annular plaques, often with vesicles at their periphery. This infection has been widely reported in wrestlers and is often referred to as tinea gladiatorum, trichophytosis gladiatorum and tinea corporis gladiatorum. Several studies have examined the epidemiology of tinea corporis gladiatorum in wrestlers. It was found that the rate of affected wrestlers in wrestling teams varies from $24 \%$ to $77 \%$. Another study on teams of asymptomatic wrestlers found that about $24 \%$ of athletes were carriers. ${ }^{27-30}$

Tinea capitis is less common in athletes. This condition mostly affects people who practice sports that entail close contact among the athletes and those using protective equipment, e.g., jockeys and hockey players. ${ }^{31-33}$

Tinea versicolor, a condition caused by a fungus (Malassezia furfur), is a another relatively frequent superficial skin infection. ${ }^{34}$ Its occurrence is associated with individual predisposition, excessive sweating, humidity, and closefitting clothing. Recurrences of the disease are frequent among athletes.

\section{Infestations: Scabies and head lice}

Scabies and pediculosis of the head, torso and pubic area are parasitic diseases caused by ectoparasites that live on or in the skin of the host. These infestations may be challenging to diagnose; however, their treatment is easy. Ectoparasitoses are highly contagious by a direct headto-head or body-to-body contact. Symptoms may appear 3-4 weeks after infection, which hampers the diagnosis, delays treatment and facilitates the spread of the parasites. ${ }^{3}$

The most common sign of pediculosis is intense itching on the scalp, torso or in the pubic area - parts of the body covered by hairy skin. The diagnosis is based on clinical examination and detection of live lice or viable nits. Using sticky tape over the infected area to collect lice for a microscope examination can be helpful. If only nits are found on the hair shafts, in the absence of nymphs or adult lice, then a recent infestation can be suspected, but active disease cannot be confirmed. ${ }^{35}$ Medicinal shampoos with permethrin, phenothrin or carbaryl are effective therapeutic agents. ${ }^{36}$

Symptoms of scabies include an itchy, lumpy rash, often with vesicles, pustules or lumps. It is caused by the mite Sarcoptes scabiei, which burrows into the skin. Scabies can be suspected when the characteristic skin appearance and distribution of lesions are seen; however, a proper diagnosis can be confirmed by identifying the mite or mite eggs in skin scrapings under a low-power microscope. The treatment of choice is a topical permethrin cream. ${ }^{37}$

When combating scabies and pediculosis, maintaining clean bed linens and towels is important. Textiles should be washed in hot water with a regular laundry detergent to reduce the risk of re-infestation. In the case of fabrics that are difficult to wash at high temperatures, it is helpful to put them in plastic bags and keep them for 7 days at a low room temperature or freezer. The basis of epidemiological treatment is the simultaneous treatment of all the people who have close contact with the infected individual. ${ }^{38}$

\section{Conclusions}

Skin infections and related skin lesions are a common problem among people who practice sports disciplines, especially those with direct skin-to-skin contact. Protecting against infections and the transmission of pathogens in sports teams is crucial in avoiding unnecessary morbidity and minimizing any disruption to the training and competition schedule.

\section{ORCID iDs}

Danuta Nowicka (D) https://orcid.org/0000-0002-1717-4280 Marta Bagłaj-Oleszczuk (D) https://orcid.org/0000-0002-4554-7603 Joanna Maj (D) https://orcid.org/0000-0001-8300-8208

\section{References}

1. Warburton DER, Nicol CW, Bredin SSD. Health benefits of physical activity: The evidence. CMAJ. 2006;174(6):801-809.

2. Derya A, llgen E, Metin E. Characteristics of sports-related dermatoses for different types of sports: A cross-sectional study. J Dermatol. 2005;32(8):620-625.

3. Peterson AR, Nash E, Anderson BJ. Infectious diseases in contact sports. Sports Health. 2019;11(1):47-58.

4. Herzog MM, Fraser MA, Register-Mihalik JK, Kerr ZY. Epidemiology of skin infections in men's wrestling: Analysis of 2009-2010 through 2013-2014 National Collegiate Athletic Association surveillance data. J Ath/ Train. 2017;52(5):457-463.

5. Yard EE, Collins CL, Dick RW, Comstock RD. An epidemiologic comparison of high school and college wrestling injuries. Am J Sports Med. 2008;36(1):57-64.

6. Börjesson M, Arvidsson D, Rensburg CJV, Schwellnus M. Return to play after infectious disease. In: Musahl V, Karlsson J, Krutsch W, Mandelbaum BR, Espregueira-Mendes J, d'Hooghe P, eds. Return to Play in Football. Berlin-Heidelberg: Springer Verlag; 2017:755-769.

7. Kirkland R, Adams BB. Dermatological problems in the football player. Int J Dermatol. 2006;45(8):927-932.

8. Sosin DM, Gunn RA, Ford WL, Skaggs JW. An outbreak of furunculosis among high school athletes. Am J Sports Med. 1989;17(6):828-832.

9. Young LM, Motz VA, Markey ER, Young SC, Beaschler RE. Recommendations for best disinfectant practices to reduce the spread of infection via wrestling mats. J Ath/ Train. 2017;52(2):82-88.

10. Champion AE, Goodwin TA, Brolinson PG, Werre SR, Prater MR, Inzana TJ. Prevalence and characterization of methicillin-resistant Staphylococcus aureus isolates from healthy university student athletes. Ann Clin Microbiol Antimicrob. 2014;13:33.

11. Belongia EA, Goodman JL, Holland EJ, et al. An outbreak of herpes gladiatorum at a high-school wrestling camp. N Eng J Med. 1991; 325(13):906-910.

12. Freeman MJ, Bergfeld WF. Skin diseases of football and wrestling participants. Cutis. 1977;20(3):333-341. 
13. Bergfeld WF, Taylor JS. Trauma, sports, and the skin. Am J Ind Med. 1985;8(4-5):403-413.

14. Selling B, Kibrick S. An outbreak of herpes simplex among wrestlers (herpes gladatorum). N Engl J Med. 1964;270:979-982.

15. Anderson BJ. The epidemiology and clinical analysis of several outbreaks of herpes gladiatorum. Med Sci Sports Exerc. 2003;35(11):1809-1814.

16. Usatine RP, Tinitigan R. Nongenital herpes simplex virus. Am Fam Physician. 2010;82(9):1075-1082.

17. Jefferis J, Perera R, Everitt $\mathrm{H}$, et al. Acute infective conjunctivitis in primary care: Who needs antibiotics? An individual patient data metaanalysis. Br J Gen Pract. 2011;61(590):e542-e548.

18. Johnson R. Herpes gladiatorum and other skin diseases. Clin Sports Med. 2004;23(3):473-484.

19. Meza-Romero R, Navarrete-Dechent C, Downey C. Molluscum contagiosum: An update and review of new perspectives in etiology, diagnosis, and treatment. Clin Cosmet Investig Dermatol. 2019;12:373-381.

20. Adams BB. Which skin infections are transmitted between athletes? West J Med. 2001;174(5):352-353.

21. Freiman A, Barankin B, Elpern DJ. Sports dermatology part 1: Common dermatoses. CMAJ. 2004;171(8):851-853.

22. Choong KY, Roberts LJ. Molluscum contagiosum, swimming and bathing: A clinical analysis. Australas J Dermatol. 1999;40(2):89-92.

23. Bassiri-Jahromi S, Sadeghi G, Asghari Paskiaee F. Evaluation of the association of superficial dermatophytosis and athletic activities with special reference to its prevention and control. Int J Dermatol. 2010;49(10):1159-1164.

24. Gnat S, Łagowski D, Nowakiewicz A, Dyląg M. Tinea corporis caused by Trichophyton equinum transmitted from asymptomatic dogs to two siblings. Braz J Microbiol. 2020;51(3):1433-1438.

25. Peixoto RRGB, Meneses OMS, da Silva FO, Donati A, Veasey JV. Tinea capitis: Correlation of clinical aspects, findings on direct mycological examination, and agents isolated from fungal culture. Int J Trichology. 2019;11(6):232-235.
26. Grosset-Janin A, Nicolas X, Saraux A. Sport and infectious risk: A systematic review of the literature over 20 years. Med Mal Infect. 2012; 42(11):533-544.

27. Beller M, Gessner BD. An outbreak of tinea corporis gladiatorum on a high school wrestling team. J Am Acad Dermatol. 1994;31(2 Pt 1): 197-201.

28. Adams BB. Tinea corporis gladiatorum: A cross-sectional study. J Am Acad Dermatol. 2000;43(6):1039-1041.

29. Ilkit M, Saracli M, Kurdak H, et al. Clonal outbreak of Trichophyton tonsurans tinea capitis gladiatorum among wrestlers in Adana, Turkey. Med Mycol. 2009;48(3):480-485.

30. Kaushik N, Pujalte GG, Reese ST. Superficial fungal infections. Prim Care. 2015;42(4):501-516.

31. John AM, Schwartz RA, Janniger CK. The kerion: An angry tinea capitis. Int J Dermatol. 2018;57(1):3-9.

32. Hay RJ. Tinea capitis: Current status. Mycopathologia. 2017;182(1-2): 87-93.

33. Auchus IC, Ward KM, Brodell RT, Brents MJ, Jackson JD. Tinea capitis in adults. Dermatol Online J. 2016;22(3):13030/qt4dm9s3fh.

34. Renati S, Cukras A, Bigby M. Pityriasis versicolor. BMJ. 2015;350:h1394.

35. Hatam-Nahavandi K, Ahmadpour E, Pashazadeh F, et al. Pediculosis capitis among school-age students worldwide as an emerging public health concern: A systematic review and meta-analysis of past five decades. Parasitol Res. 2020;119(10):3125-3143.

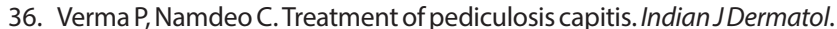
2015;60(3):238-247.

37. Flinders DC, De Schweinitz P. Pediculosis and scabies. Am Fam Physician. 2004;69(2):341-348

38. Gunning K, Pippitt K, Kiraly B, Sayler M. Pediculosis and scabies: Treatment update. Am Fam Physician. 2012;86(6):535-541. 